\title{
Work Readiness of Software Engineering Student in Batu City
}

\author{
Agung Panji Sasmito \\ Doctoral Student of Vocational Education Program, Post Graduate, Universitas Negeri Malang \\ Jl. Semarang 5 Malang Indonesia \\ ajungpangi@y ahoo.com
}

\begin{abstract}
The objective of the research is to describe the work readiness of the vocational school students of Software Engineering in Batu City. The research design is a survey study conducted on 56 students of 12 grade Software Engineering in Batu City. Data collection of work readiness variable using questionnaire. Based on the results of the research note that in general the readiness of student work is low.
\end{abstract}

Keywords-work readiness, Software Engineering student

\section{INTRODUCTION}

Vocational education is basically in charge of providing useful skills to prepare young people to enter the workforce and increase their chances of getting a successful professional career [1] and responding employer's need [2]. Vocational education as an organized educational program directly related to the preparation of individuals to enter the workforce [3] with its particular technical knowledge to be able to adapt to the world of work [4] [5] has criteria that must be possessed by vocational education that is the orientation of individual performance in the world of work according to real needs in the field [6] [7]. In other words, the success ness of vocational education can be seen from its graduates who are ready to work which meet the labor needs of the employer.

But in reality vocational education has not provided optimal solutions related to employment problems in the community. According to Badan Pusat Statstik (Indonesian Central Bureau of Statistics) data in 2014, the number of unemployed vocational graduates is $11.24 \%$ of total unemployment, greater than the percentage of general high school graduates which only reach $9.55 \%$ [8]. Until the end of 2016, data on productive unemployment graduated from vocational school is $1,348,327$ people [9]. From the description it is seen that the vocational school that play a role preparing graduates to enter the world of work in fact the graduates are not absorbed into the employment optimally.

Batu city also experienced problems absorption of vocational graduate. Based on the preliminary observation of the research conducted by the researcher obtained the data of vocational school graduate of Software Engineering expertise in Batu City which is absorbed by work equal to $49,15 \%$, graduates continuing study equal to $37,29 \%$, and the rest equal to $13,56 \%$ not yet work or unemployed.
The low quality of human resources became one of the factors triggering the low absorption of vocational school graduate to industrial world, until its unemployment rate is high [10] [11]. Vocational school graduates do not have adequate skills to work in the world of work [12]. Prospective workers tend to have low work skills and have little work experience or relevant job skill to offer to employer [13] [14], until the issue of skill gap between graduates and employer needs. This is reinforced by a World Bank report that mentions the existence of skill gap conditions in Indonesia, namely the gap between the industrial world skill demand and that of the output of vocational education in Indonesia [15]. This has resulted in many potential employers failing to meet the expectations of employers. Graduates who become candidates for labor are in fact not ready to compete especially with workers from abroad, if momentum such as ASEAN Economic Community and APEC are currently being discussed warmly. This gap is caused by competency factors of vocational high school graduates who are still low and the mental condition of low graduates that are not yet ready to enter the world of work. Therefore, in this research will be studied readiness of vocational school students of Software Engineering in Batu City.

\section{LITERATURE REVIEW}

Readiness is the rate of development of maturity that is advantageous to take practice [16]. Readiness can be interpreted as the ability, desire, and to perform certain activities that joins the maturity level of previous experiences and appropriate mental conditions [17]. Readiness is the overall state of a person who makes it ready to respond in some way to a situation [18]. Thus, the readiness of work is the level of readiness of students to work in the business world or industry after graduating from school, especially vocational school. Such readiness includes the physical and mental ability to be able to complete the work with good and maximum results. Business world or industry referred to in this research is the scope of work on the package of Software Engineering expertise.

When viewed in the context of industrial linkage with vocational school, it can be concluded that the readiness of work is the ability of students according to his condition to work in labor. The work readiness in this context is the 
readiness of students as candidates for graduates to work especially in industrial world. Work readiness can be defined as to what extent graduates feel to have attitudes and traits that make them prepared or ready to succeed in the work environment [19].

Work readiness can be said as the readiness of students to be able to adjust to the culture and workplace demands [20]. Work readiness is the bridge that connects work-oriented learning with the skills required by the world of work [21]. Reference [22] mentions that work readiness refers to the extent to which graduates already have attitudes, skills, and knowledge that can prepare them for success in the workplace. Therefore, the readiness of students to work is an important thing to improve, because job readiness is one benchmark to measure the appropriateness of graduates with employer needs.

\section{METHOD}

This research is using descriptive research with quantitative research approach. In this study, the population is all Software Engineering students of 12 grade in Batu city. Batu city was chosen as a research location because Batu City is identical as center of tourism, especially in East Java, Indonesia [23]. Promotion is inseparable part from tourism development [24], including digital promotion such as through social media [25]. Social media is delevoped by information systems, one of the main skills of the Software Engineering expertise package.

Proportional random sampling technique is used as sampling technique in this research. The Taro Yamane formula is used to determine the sample size of a population [26]

$$
n=\frac{N}{N d^{2}+1}=\frac{64}{64 \times 0,05^{2}+1}=55,172 \approx 56
$$

Based on the calculation with the formula obtained a sample of 56 people with rounding up. To simplify the distribution of the questionnaire, then the number of each sample according to the school by using the proportional allocation formula [26]. The number of population and school samples is presented in Table 1 .

TABLE I. POPULATION AND SAMPLE DATA

\begin{tabular}{|c|c|c|c|}
\hline No. & School Name & $\begin{array}{c}\text { Number of } \\
\text { Population }\end{array}$ & $\begin{array}{c}\text { Number of } \\
\text { Sample }\end{array}$ \\
\hline 1. & SMK Maarif Batu & 33 students & 29 students \\
\hline 2. & SMK Islam Batu & 31 students & 27 students \\
\hline \multicolumn{2}{|c}{ Total } & 64 students & 56 students \\
\hline
\end{tabular}

Questionnaire is used as research instrument in this study. Questionnaires in this study is using Likert scale with four alternative answers, namely: (1) strongly agree or very appropriate; (2) agree or comply; (3) disagree or not agree; and (4) strongly disagree or strongly disagree [26]. The trial test of the instrument includes a validity test and a reliability test. Testing of construct validity is carried out with the opinion of experts (judgment experts) [26]. Experts used in testing instrument validity are: (1) Dr. Eddy Sutadji, M.Pd, as a vocational education expert; and (2) Dr. Hakkun Elmunsyah, M.T, as the Software Engineering expert.

After completion of the test constructs from the experts, it is continued to test the validity of the instrument with Pearson Product Moment correlation [26]. Validity test conducted on the population that is not selected as sample, which is a number of 8 students. Instrument validity testing is calculated by IBM SPSS Statistics version 24. Instrument items are valid if the significance is smaller than the real level of 0.05. Based on result between significance with 0,05 is known that number of valid item of questionnaire is 25 item. The invalid ones with significance close to 0.05 was corrected for use as an instrument.

The instrument reliability test then performed using Cronbach Alpha coefficient [26]. A construct or variable is said to be reliable if it gives a Cronbach Alpha value greater than 0.6 [27]. Instrument reliablity testing performed with IBM SPSS Statistics version 24. Cronbach Alpha value for the instrument is 0.977 . From those results, it was decided that the whole instrument would be reliable.

\section{RESULT}

Job readiness $(\mathrm{X})$ disclosure is conducted through a review of indicators: (1) X1 is the level of work skills; (2) X2 is the courage to take risks; (3) X3 that is oriented to the future; and (4) X4 is self-confidence. Descriptive test results are shown in Table 2.

TABLE II. DESCRIPTIVE TEST RESUlt

\begin{tabular}{|c|c|c|c|c|c|}
\hline No & Indicators & Mean & Category & $\begin{array}{c}\% \\
\text { Category }\end{array}$ & Criteria \\
\hline X1 & $\begin{array}{c}\text { Job skill } \\
\text { level }\end{array}$ & 36,29 & Low & $80,63 \%$ & $\begin{array}{c}\text { In } \\
\text { general }\end{array}$ \\
\hline X2 & $\begin{array}{c}\text { Courage to } \\
\text { take risks }\end{array}$ & 17,70 & Low & $73,74 \%$ & Mostly \\
\hline X3 & $\begin{array}{c}\text { Future } \\
\text { oriented }\end{array}$ & 14,63 & Low & $73,13 \%$ & Mostly \\
\hline X4 & $\begin{array}{c}\text { Confidence } \\
\text { X }\end{array}$ & 15,41 & Low & $81,11 \%$ & $\begin{array}{c}\text { In } \\
\text { general }\end{array}$ \\
\hline $\mathbf{X}$ & $\begin{array}{c}\text { Work } \\
\text { readiness }\end{array}$ & $\mathbf{8 4 , 0 2}$ & Low & $\mathbf{7 7 , 7 9 \%}$ & $\begin{array}{c}\text { In } \\
\text { general }\end{array}$ \\
\hline
\end{tabular}

\section{DISCUSSION}

The results showed that in general the level of work skills and confidence included in the low category. Indicators of risk-taking and future-oriented students are mostly low-level. Based on the results of descriptive analysis of the work readiness in generally belong to low category. Based on this matter, it can be seen that the readiness of students of Software Engineering expertise in Batu city is in low level. The low level of readiness of students to work is mainly 
caused by the low factor of students' job skill level with achievement of mean equal to 36,29 and student's self confidence with achievement of mean equal to 15,41 .

Reference [28] outlines the criteria that every graduate should have for work includes competencies: (1) specific vocational knowledge and skills in accordance with the cluster of work; (2) specific social, emotional, and social knowledge and skills in social life; (3) basic knowledge and skills; and (4) general, social, and academic knowledge and skills. The four competencies can be summarized into two major groups, namely: (1) hard skill competence, which includes vocational competence and basic competence; and (2) soft skill competencies such as mental and emotional competence. This is reinforced by the results of the research on references [29] and [30] which indicate there are two competencies that must be possessed by the prospective workforce required by labor, namely: (1) specific competence or hard skills, ie competencies corresponding to the field their respective expertise; and (2) general competence or soft skill, that is general competence for prospective worker demanded by employer including from mental aspect. Prospective workers which required by labor is a candidate for workers who have comprehensive competence, which is a blend of hard skill competence and soft skills [31]. Thus, to improve the readiness of students work required the active role of school and industrial world by increasing the hard skills and soft skills of students.

The hard skills aspect from the graduate can be reflected in the acquisition of technical and vocational competencies that illustrate how much of the students' productive learning experiences. The high-degree of its acquisition suggests that the student mastered well the educational and training materials taught in school [32]. The higher rate of the mastery of competency owned by students, the more of the ability obtained by students according to their respective areas of expertise. Productive subjects are one of provisions of the students to work in the workforce, because one aspect of employment is a specific competence or hard skill in the form of competence in accordance with their respective areas of expertise [29] [30]. Therefore, the higher provision of the expertise can promote students more ready to be accepted to work in labor.

Although hard skill is high, the student is not always suitable with the needs of the required labor of industrial world. In fact, vocational school graduates have not been able to meet the needs of employer who are ready to work and skilled in a specific field [33]. References [34] states that vocational school in Indonesia has not been able yet to be prepared, trained, and ready to work. This is because not all vocational schools are able to implement educational programs that can provide students which match with employer's need [34]. The job skill of the vocational school graduates is still not as expected criteria of labor. In addition, most graduates are still less able to adapt to the changes and developments in science and technology required by industrial world [35]. The technology in vocational school is outdated and caused gap between technology used in vocational school with technology used by industry [14] [36]. The technology used by students during school learning is obsolete compared to the technology used by industrial world.

References [37] states that in assessing the quality of vocational graduates which will be recruited for work, employer prioritizes aspects of soft skill graduates rather than their hard skills. This is in accordance with the observation results of some industrial partners of Software Engineering vocational school in Batu city which shows that employer is not paying much attention to hard skill of graduates because they will be given training for some time to prospective workers related to specific job that they will carry out in industry. The industrial partners much prefer the candidate which has ourage to take risks, future oriented, have confidence, diligent and honest. Reference [38] [39] pointing out that in the labor recruitment system the soft skill aspect is more emphasized than the hard skill or level of education. Soft skills are much more considered than hard skills in the system of recruitment of workers [40] [41], because the soft ones are more necessary for workers to be productive and to work efficiently [39]. Therefore, the prospective worker required by the workplace is a candidate for workers who have comprehensive competence, which is a blend of competence hard skills that are qualified and supported by a good soft skill [31].

\section{CONCLUSIONS AND RECOMMENDATIONS}

Based on the results of research that has been done, it can be concluded that generally the work readiness of students is in low levels. In other words, Software Engineering graduates in Batu city have not been optimally ready to go to work in labor yet.

Based on the research results, suggestions that can be given are as follows. To further improve the work readiness of students it is recommended that students could always optimize their potential with the active guidance by the school and labor both good quality on hard skills and soft skills. Recommendations to further research on work readiness based on the findings of this study are expected: (1) further research can be carried out in a wider range of areas such as at the level of province or district; and (2) the researcher can further examine the work readiness of the students by connecting with the contribution of other variables such as hard skill or soft skill.

\section{REFERENCES}

[1] W. Eichhorst, et al. "A Roadmap to Vocational Education and Training Systems Around the World”, Bonn: Iza, 2012.

[2] Gelişli, Y., L.Beisenbayeva, M.Z.Sultanbek, \& A.Ussenova. 2016. Vocational Education Systems In Turkey And The World: New Trends And Problems, International Journal on New Trends in Education and Their Implications, 7(3): 1-10.

[3] C.C. Calhoun \& A.V.Finch, "Vocational Education: Concepts and Operations", California: Wadsworth Publishing Company, 1982.

[4] Mortaki, S. 2012. The Contribution of Vocational Education and T raining in the Preservation and Diffusion of Cultural Heritage in Greece: The 
Case of the Specialty "Guardian of Museums and Archaeological Sites". International Journal of Humanities and Social Science, 2(24): 51-58.

[5] Elebute, A. \& O.S.Mashood. 2016. Impact Of Vocational And Technical Education On Livelihood Sustenance And Economic Development In Nigeria: The Art Workshop Experience. International Journal of Vocational and Technical Education Research, 2(2): 15-35.

[6] S. Billet, "Vocational Education: Purposes, Traditions, and Prospects", New York: Springer, 2011

[7] C.R Finch and J.R.Crunkilton, "Curriculum Development in Vocational and Technical Education Third Edition”, Boston: Allyn and Bacon Inc., 1989.

[8] Tempo, "Lulusan SMK Mendominasi Jumlah Pengangguran", (Online), (http://www.tempo.co/read/news/2014/11/05/090619808/Lulusan-SMKMendominasi-Jumlah-Pengangguran), November 5, 2014.

[9] Badan Pusat Statistik, "Pengangguran Terbuka Menurut Pendidikan Tertinggi yang Ditamatkan 1986 - 2016", (Online), (https://www.bps.go.id/linkTabelStatis/view/id/972), Oktober 20, 2016.

[10] R.T .Akor, P.P.Agashi, F.T.Ekuje, J.A.Akoh, \& E.S.Ebenehi, "Technical And Vocational Education: A Solution To Precarious Youth Unemployment In Nigeria" in European Journal of Education Studies, vol 2(11), pp.155-167, 2016

[11] C.S.Ayonmike \& B.C.Okeke, "Bridging The Skills Gap And Tackling Unemployment Of Vocational Graduates Through Partnerships In Nigeria" in Journal of Technical Education and Training, vol 8(2), pp.1$11,2016$.

[12]G. J. Soputan, "Are Vocational High School Students Ready to be Entrepreneur?" in Innovation of Vocational Technology Education, vol 13(2), pp.45-49, 2017.

[13]M. Piopiunik and P. Ryan, "Improving The Transition Between Education/Training and The Labour Market: What Can We Learn from Various National Approaches?", Munich: European Expert Net work on Economics of Education, 2012.

[14] J.I.Oviawe, R.Uwameiye, \& P.S.O.Uddin, "Bridging Skill Gap to Meet Technical, Vocational Education and Training School-Workplace Collaboration in the 21 st Century?" in International Journal of Vocational Education and Training Research, vol 3(1), pp.7-14, 2017.

[15]World Bank. "Indonesia Skills Report Trends in Skills Demand, Gaps, and Supply in Indonesia", W ashington: Human Development Department East Asia and Pacific Region, 2010.

[16]J.P. Chaplin, "Kamus Lengkap Psikologi”, Jakarta: PT Rajagrafindo Persada, 2002.

[17]I.S. Sumarsih, "Kontribusi Praktik Industri terhadap Minat Siswa dalam Berwirausaha di Bidang T ata Busana pada Siswa Kelas XII Tata Busana SMK Negeri 6 Yogyakarta”. Yogyakarta: Universitas Negeri Yogyakarta, 2010.

[18]Slameto, "Belajar dan Faktor-Faktor Yang Mempengaruhi”, Jakarta: Rineka Cipta, 2013

[19]C.L. Caballero et al., "The Work Readiness Scale (WRS): Developing a Measure to Assess Work Readiness in College Graduates". In Journal of Teaching and Learning for Graduate Employability, vol 2(2), 2013, pp.41-54

[20]A.J. Parker, "Career and Technical Education and Workplace Readiness of High School Students". Athena: University of Georgia, 2011.

[21] S.Bandaranaike \& J.Willison, "SBuilding Capacity for Work-Readiness: Bridging the Cognitive and Affective Domains" in IAsia-Pacific Journal of Cooperative Education, vol 16(3), pp.223-233, 2015.

[22]D. Kwok et al, "Work Readiness: A Study of Student Intern's SelfPerception and Supervisor Evaluation", Singapore: Centre for Development of Teaching and Learning National University of Singapore, 2014.

[23]C.A.D.Kirana, A.Suryono, \& Suryadi, "Implementation of Tourism Destination Development Program in Batu City" in International Journal of Management and Administrative Sciences, vol 4(7), pp.34-39, 2017

[24]A.Răvar, "The Importance of Print and Visual Media in the Promotion of Hospitality Enterprises" in Cact us Tourism Journal, vol 2(2), pp.93-98, 2011.

[25]G.Kaur, "The Importance Of Digital Marketing In The Tourism Industry" in International Journal of Research - Granthaalayah, vol 5(6), pp.72-77, 2017.

[26]Riduwan, "Metode dan Teknik Menyusun Tesis", Bandung: Alfabeta, 2007.
[27]I. Ghozali, "Aplikasi Analisis Multivariate dengan Program SPSS". Semarang: Badan Penerbit Universitas Diponegoro, 2009.

[28]F.C. Butler, "Instructional Systems Development for Vocational and Technical Training", New Jersey: Educational Technology Publications Inc, 1972.

[29]Y.A. Agung, "Analisis Hasil Needs Assessments DUDI dan Studi Pelacakan Tamatan SMK", Yogyakarta: PPs Universitas Negeri Yogyakarta., 2009.

[30]H. Suswanto, "Momentum Rekonstruksi Pendidikan Vokasi terhadap Kajian Konfigurasi Tenaa Kerja di Indonesia pada Abad ke-21", Malang: Jurusan Teknik Elektro Universitas Negeri Malang, 2011.

[31] R.H.Binsaeed, S.T.Unnisa, \& L.J.Rizvi, "The Big Impact Of Soft Skills In Today's Workplace" in International Journal of Economics, Commerce and Management, vol 5(1), pp.456-463, 2017.

[32]Sulistianingsih, "Kontribusi Motivasi untuk Bekerja dan Prestasi Belajar AutoCAD terhadap Kesiapan Kerja Siswa di Bidang Jasa Konstruksi", Malang: PPs Universitas Negeri Malang, 2014.

[33] E.J.Munishi, "Factors Contributing To Lack Of Employable Skills Among Technical And Vocational Education (Tvet) Graduates In Tanzania" in Business Education Journal, vol 1(2), pp.1-19, 2016.

[34]Murniati and N.Usman, "Implementasi Manajemen Stratejik dalam Pemberdayaan Sekolah Menengah Kejuruan”, Bandung: Citapustaka Media Perintis, 2009.

[35]R. Hidayat, "Pendidikan Kecakapan Hidup pada Program Keahlian Teknik Otomotif SMK Negeri 1 Sutera Kabupaten Pesisir Selatan”, Padang: Universitas Negeri Padang, 2013

[36] S.Nooruddin, "FTechnical and Vocational Education and Training for Economic Growth in Pakistan" in Journal of Education and Educational Development, vol 4(1), pp.130-141, 2017.

[37] S.Anthony \& B.Garner, "Teaching Soft Skills to Business Students" in Business and Professional Communication Quarterly, vol 79(3), pp.360 $370,2016$.

[38]D.A. Sudjimat, "Pengembangan Kecakapan Kemampukerjaan untuk Meningkatkan Kualitas SDM Unggul Abad XXI", Malang: UM Press, 2013.

[39]C.Y.T sai, "A Study of Employability between Higher Technical and Vocational Education and Employer in Tourism and Hospitality: A Stakeholder Perspective", in International Journal of Academic Research in Business and Social Sciences, vol 3(10), pp.344-357, 2013.

[40]Z. Othman et al, "Undergraduate Awareness and Readiness Towards Employability: The Significance of English", in British Journal of Arts and Social Sciences, Vol 2(2), pp.122-142, 2011.

[41] R.Ramlan \& S.Ngah, "Student Perception On The Importance Of Soft Skills For Education And Employment" in International Journal of Social Sciences, vol 1(1), pp.696-708, 2015. 